DOI: 10.7596/taksad.v3i2.319

\title{
Doğu-Batı Ayrımı Ekseninde Oryantalizm ve Emperyalizm
}

\author{
Erkan Dikici $^{1}$
}

$\ddot{O} \mathbf{z}$

Bu çalışma, Doğu ile Batı arasındaki ilişkiyi incelemek adına Edward Said tarafından 1978 yılında kaleme alınan "Oryantalizm” kitabında ifade edilen oryantalist yaklaşımdan yola çıkarak, Doğu-Batı ayrımına vurgu yapmakta ve bu ayrımın arkasında yatan çıkar ilişkilerini dile getirmeye çalışmaktadır. Söz konusu Doğu-Batı ayrımı ile birlikte oryantalizm ile emperyalizm arasındaki ilişkiye de temas edilmek istenmiştir. Bu ilişkiler zinciri içerisinde dile getirdiğimiz bu ayrım, Batılıların, Batılı olmayan toplumlar üzerindeki emperyalist düşünceleri uygulayabilmek amacıyla, Batılıların kendileri tarafından ortaya çıkartılmıştır. Bu nedenle çalışmanın temel amacı, Batılıların, ötekileştirdiği Batı-dışı toplumlar üzerindeki emellerine ulaşmada oryantalizmi biçilmiş kaftan olarak görmekte olduklarını ve oryantalizmi, emperyalizmin meşrulaştırıcısı olarak düşündüklerini ifade etmektir.

Anahtar Kelimeler: Oryantalizm, Doğu-Batı Ayrımı, Emperyalizm, Ötekileştirme.

\footnotetext{
${ }^{1}$ Bitlis Eren Üniversitesi Öğretim Görevlisi.
} 


\section{Orientalism and Imperialism within the Concept of East-West Division}

This study emphasizes the East-West division based upon the orientalist approach stated in the book "Orientalism" written by Edward Said in 1978 to study the relation between the East and the West, and tries to depict the relationships based on self-interest underlying this division. With the aforesaid East and West division, it is also wanted to mention the relation between orientalism and Imperialism. The division that we have mentioned has been posed by the Westerners to carry out their imperialist thoughts over nonwestern societies. For his reason, the main aim of this study is to express that the westerners see orientalism perfectly suited to reach their goals over non-western societies that they have otherized, and they also think orientalism as the legitimization of imperialism.

Keywords: Orientalism, East-West Division, Imperialism, Othering.

Giriş

Oryantalizm kavramı, zaman zaman olumsuz bir anlam yüklenerek kullanılan ve özellikle 18. ve 19. yüzyıllarda biçimlenmiş, Batılı araştırmacıların Doğu'ya ilişkin yaptıkları çalışmaları dile getirmek amacıyla kullanılmaya başlanmış bir kavramdır. Batılı bir araştırmacı veya bilim adamının Doğu'yu konu alarak yaptığı çalışmaya "oryantalistik" çalışma denilmektedir. Kimilerine göre Oryantalizm kavramı içerisindeki olumsuzluk aslında buradan kaynaklanmaktadır. Batı, kendisi dışındaki, Batılı-olmayan toplumlara karşı, bir yaşam tarzı veya bir kültür ve medeniyet silsilesi ortaya koymuş ve bunu da oryantalizm adı altında dile getirmeye çalışmıştır. Batı'nın, Doğu'ya yönelik bu bakış açısı, aslında dışlayıcı ve ötekileştirici bir içeriğe sahiptir.

Oryantalizmin, Batı'nın Doğu'ya bakışını ifade eden akademik bir disiplin olduğu düşünülmektedir. Bu disiplin altında her kesimden bilim adamı ya da sanatçı, Doğu ile ilgili düşüncelerini ortak paydada bir araya getirmeye çalışmıştır. Oryantalizm adı altında yapılan bu çalışmalar, belirli bir döneme kadar olumlu karşılanmış, ardından sömürgeci anlayışa hizmet ettiği düşüncesinden dolayı olumsuz bir anlam yüklenmiş ve eleştirilmeye başlanmıştır. Oryantalizmin olumsuzlanmasının ardında yatan temel sebep, onun “ötekileştirici” olma fonksiyonu olduğu söylenebilir; fakat ötekileştirmenin yanı sıra sömürgeciliğin de ilişkilendirilmesi gerektiği, bu çalışmanın anlatmak istediği düşüncelerden birisidir. Çünkü Batı, “öteki” olarak nitelediği Doğu toplumları için çeşitli dışlayıcı bakış açıları geliştirmiştir ve emperyalizmi de beraberinde uygulamıştır. 
Kızılçelik'e göre (Kızılçelik, 2003:113), Anouar Abdel-Malek ve daha çok Edward Said'in çalışmaları ile gündeme gelen, akademik bir çalışma alanı ve bilimsel bir konu olarak kavranan oryantalizm, bilgi birikimi ile güç arasındaki yakın ilişkiyi inceleme bağlamında Batılı olmayan uygarlıkların genel görünümlerine, yapılarına ve özelliklerine ilişkin soyut bir anlayışa karşılık gelmektedir. Bu bağlamdan hareketle, oryantalizm, Batı'nın Doğu'ya yönelişi ve bunun sonucunda ortaya çıkan bakış açısını gözler önüne sermesi bakımından ortaya çıkmış bir disiplin olma özelliğine sahiptir.

Edward Said, Oryantalizm isimli eserini yazmasıyla birlikte birçok alanda yeni bakış açıları ortaya çıkmıştır. Özellikle oryantalizm üzerine kafa yoran Batılı bilim adamları ya da düşünürler üzerinde önemli bir kaynak olmuştur. Eserin yazılmasıyla çok sayıda eleştiri de kaleme alınmıştır. Özellikle bu eserin yazılmasının ardından, Avrupa-merkezcilik, Doğu-Batı ayrımı, ötekileştirme ve sömürgecilik üzerine Batı zihniyetinin geldiği nokta gözler önüne serilmiştir. Said'in çalışmasıyla birlikte Batı'nın, Doğu karşısında geliştirdiği emperyalizm ve Avrupa merkezci bakış açısı, daha net görülebilmektedir.

Said'in, oryantalizm görüşlerine, sömürgeciliğin keşif kolu olarak bakacak olursak; oryantalizm ve emperyalizm gibi kavramların Avrupa'nın üstünlüğü esasına dayanan Batı sömürge kültürüne ait olduğu söylenebilir. Batı üstünlüğünün göstergesi olan oryantalizm, öncelikle teorik olarak bilgi üretme adına ideolojik bir misyon üstlenmiştir. Sonra da üretilen bu bilgiler, emperyalizm düşüncesi ekseninde pratiğe dökülmektedir. Yani oryantalizm, emperyalizmin kendini gerçekleştireceği bir alan yaratmaktadır. Raimondo Lugarhi'nin şu sözü, oryantalizmin temel tezini ortaya koyarken, oryantalizm ile sömürgeciliğin bağlantısını da en güzel şekilde ifade etmektedir: "Beyazlar Afrika'ya geldiklerinde bizim topraklarımız, onların İncilleri vardı. Bize gözlerimizi kapatarak dua etmeyi öğrettiler. Uyandı̆̆ımızda gördük ki, onların toprakları bizim İncillerimiz vardı.” (Lugarhi, 2000:203).

Batı, bilinçli olarak kendi dışında kalan, Batılı-olmayan toplumlara karşı dışlayıcı bir anlayış geliştirerek Doğu-Batı ayrımını başlatmıştır. Bunun neticesinde Batı, kendisini, Doğu'nun karşısında merkezi bir yere taşımıştır. Bu süreçte Batı, kendini bir merkez olarak görürken, çevresindekileri "öteki” olarak görmektedir. Ortaya çıkan bu ayrım neticesinde Batı, Doğu üzerindeki sömürgeci zihniyetini gerçekleştirmek adına meşru bir yol bulmuş olmaktadir.

\section{Oryantalizm}

Oryantalizm kavramının sözlük anlamı: "Doğu'ya ait olan ya da Doğu’yu hatırlatan her şeydir". 19. yüzyılda gelişen bir bilim dalı olan Oryantalizm, Fransızca "Orientalisme" kelimesinden türemiştir. Daha genel bir anlamla Oryantalizm : "Doğu ülkelerinin din, dil, tarih ve medeniyetlerini araştıran ilim dalıdır." (Germaner ve İnankur, 1989:9). Oryantalist (orientaliste) kelimesine gelince genel olarak, Doğu dilleri ve Doğu Bilimleri uzmanı 
anlamında olup Doğu (Şark) topluluklarının tarihini, dinini, dilini, edebiyatını, kültürünü ve diğer bazı noktalarını araştıran bilim adamı anlamında kullanılmaktadır (Sönmezsoy, 1998:25).

Orient (Doğu) tabiri, Doğu’yu, Batılı öğrenim, Batılı bilinç ve Batı imparatorluğu alanına taşıyan politik güçlerce çevrelenen temsiller sistemine işaret eder. Doğu eski çağlardan beri insanlarda hülyalar uyandıran, garip izlenimler yaratan, kendine has yaratıkları ve manzaraları ile fevkalade deneyimlere yol açan bir yerdir. Avrupalı içinse mühim olan, Doğu'nun ve olaylarının “Avrupa gözü” ile resmedilmesidir (Said, 1998:11). Said, oryantalizmi açıklama noktasında, Batı-merkezli ve Avrupa-eksenli bir kavramı ortaya koymaktadır. $\mathrm{Bu}$ açıklamalardan hareketle, oryantalizmin, Batılı-olmayan toplumlara karşı bilinçli bir ideoloji olduğu sonucuna varılmaktadır.

Oryantalizmi, Avrupa ve Batı'nın hayal ettiği Doğu'yu ifade eden bir kavram olarak düşünenlerde bulunmaktadır. Bu şekliyle oryantalizm, Batının, Doğu’yu var ettiği muazzam bir disiplin şeklinde okunmalıdır (Süphandağı, 2004:112). Buradaki önemli hususlardan birisi de, Oryantalizmin, yalnızca Batılılar tarafından Doğululara uygulanan bir anlayış olmadı̆̆ı, aynı zamanda Doğu'nun içerisinde de bu anlayışa sahip olanların olduğu şeklindedir. Yani bir entelektüel tavır olarak oryantalizm, sadece belirli bir kesim Batılıya özgü değildir. Oryantalist yaklaşımı benimsemeyen Batılılar olduğu gibi, onu benimseyen Doğulular da vardır (Şentürk, 2003:43).

O halde oryantalist, Doğu ile ilgili incelemeler yapan ve Doğu'ya dair herhangi bir konuda uzmanlaşmış Batılı bilim adamı demektir. Batılı bilim adamının çalışma alanı ise, Avrupa'nın Doğusundan itibaren bütün bir Asya ve Afrika âlemini, yakın, orta ve uzak Doğu'yu kapsamakta; tarihleri, dinleri, coğrafyaları, dilleri, kültürleri ve edebiyatlarıyla inceleme işi olarak son derece geniş bir sahaya yayılmaktadır.

Oryantalizmin birbirinden farklı tanımları yapılmaktadır. Oryantalizm, Batı dışı toplumları tanımlamaya yarayan bir teori olarak ele alındığında; Doğu yabancıdır, yeknesaktır ve tekdüzedir. Oryantalizmin Batı dışı toplumlara bakışının temel birkaç özelliği şu şekilde siralanabilir (Şentürk, 2003:45):

- Doğu toplumları geridir, Batı toplumları ileridir.

- Batı ve Doğu toplumları iki farklı varlık alanı oluşturacak derecede farklıdır.

- Doğu hep geri kalacaktır çünkü durağan ve gelişme özelliğinden yoksun toplumlardır.

- Batı toplumu dinamiktir bundan dolayı her zaman üstün ve ileri olarak kalacaktır. İleri ve geri toplumlar farklı sosyal kanunları izlediler.

- Batılı ve Doğulu toplumlar aynı sosyal teorilerle incelenemez. 


\section{Oryantalizm ve Doğu - Batı Ayrımı}

Oryantalizm hakkında yapılan tanımlardan da anlaşılacağı üzere, Avrupa ile Doğu, yani Batı ile Doğu arasına bir ayrım getirildiği rahatlıkla görülmektedir. Aslında Doğu ile Batı'nın tarih boyunca girdiği ilişkilerden, günümüzde yaşanan gelişmeleri anlamak pek zor değildir. Doğu ile Batı arasına konulan ayrımlar bir ölçüde oryantalizmin kilit noktasını oluşturmaktadır. Geniş bir yelpazeye sahip olan oryantalizmin anlaşılması için öncelikle Doğu ile Batı ayrımı üzerinde durulmalıdır. Said'in belirttiği gibi “Şark Avrupa'nın sadece komşusu değildir. Aynı zamanda Avrupa'nın en büyük, en zengin, en eski sömürgelerinin mekanı, uygarlıklarının ve dillerinin kaynağı, kültürel rakibi, en derin, en sık yinelenen öteki imgelerinden biridir.” (Said, 1998:11). Görüldüğü üzere Said, burada Doğu-Batı ayrımını vurgulamıştır.

Aslına bakılırsa Doğu ve Batı kavramları, bir coğrafi tanım da değildir. Her ikisinin de sembolleşmiş bir coğrafyaları olmasına karşın Doğu'yu ve Batı'yı belirleyen bir sınır vardır. Dolayısıyla iki taraf da değişen sınırlar etrafında sürekli bir mücadeleyle şekillenmektedir. Sınırın varlığı, bir kültürün kendiliğini belirleyen kriterlerinin olduğu anlamına gelmektedir. Yani her kültürün kendine özgü özellikleri vardır. Böylelikle bir sınırın varlığı, iki ayrı kültürün farklılığını belirtmektedir (Sunar, 2007:29-30).

Doğu-Batı ayrımından bu kadar söz edilmesine rağmen, aslında "Doğu" ve "Batı" kavramlarının herhangi bir coğrafya veya mekâna ait olmadığı görülmektedir. Coğrafi açıdan Batı olarak adlandırdığımız, "Avrupa” olsa bile, bugün Batı yalnızca Avrupa değil, tüm Avrupa da Batı değildir. Bu bağlamda düşünüldüğünde coğrafi olarak bir ayrım yapmak da bir anlam taşımamaktadır. Böylelikle Batı belirli bir coğrafi mekanı simgeleyen bir kurgu olarak değil; fakat tarihsel ve söylemsel bir kurgu olarak incelenmelidir. Bu tarihsel ve söylemsel kurgunun inşa edilmesinin temelinde, oryantalist hareketin meşrulaştırmaya çalıştı̆g emperyalist hareket bulunmaktadır; fakat çalışmada bu konuya daha sonra detaylı şekilde yer verilecektir.

Bat1 ile Doğu kavramlarının coğrafi bir terim olmaktan öte, derin anlamlara sahip olduğunu dile getiren Hilmi Ziya Ülken'e göre ise; "Doğu ve Batı" denilince, "Doğu" ve "Batı" gibi iki coğrafi yön anlaşılmaz, daha çok zihniyetleri ayrı olan iki alem, büsbütün seçik hayatları, yaşama tarzları olan iki dünya anlaşılır. Ona göre, Doğu diye kendi başına ve tek bir alem yoktur; daha çok birbirleri ile derin ilişkileri olmayan birçok alemler vardır. Genel olarak denilebilir ki; Batı'nın dışa dönük bir kültürü ve pratik ahlakı olduğu halde, Doğu'nun mistik felsefelere dayanan içedönük bir kültürü vardır. Şematik bir görüşle Doğu ve Batı'yı ruh ve madde gibi karşı karşıya koyarlar. Ancak detaya inilince bu karşıtlık değerini kaybeder: Asya kavimleri kuvvetleri ve içsel niteliklerinden büyük bölümünü yenilmeler sonunda kaybetmişlerdir. Buna karşılık, Batı da aşırı maddileşmeye rağmen, ahlaki kuvvetlerde gelişmiştir (Ülken, 1964:21). O halde, Ülken'in görüşlerinden yola çıkarak, 
Doğu-Batı ayrımı denen şeyin, aslında birbirini tamamlayan bir bütünü oluşturduğu söylenebilir. Sonuçta iki farklı kültür alanından söz edilmektedir ve bu kültürler birbirini tamamlayıcı niteliktedir. Fakat Batı, ısrarla bu bütünlüğün hakikatini inkar etmektedir. Onlara göre tek hakikat kendileridir ve bu hakikat doğrultusunda Doğu'yu, kendi istedikleri şekilde biçimlendirme düşüncesindedirler. Oryantalizmin ortaya çıkışı ve bu şekilde bir disiplin doğrultusunda çalışmalar yapılması, bu ideolojinin bir ürünüdür.

Ülken, yapmış olduğu Doğu-Batı ayrımının felsefi yönü üzerinde de durmuştur. Ona göre, bu ayrımda gerileme ve genişleme halindeki varlığın durumu vardır: Bu iki kavram sırasına göre bir yandan çaba, irade ve zekâ halinde, diğer yandan taklit ve telkin şeklinde gerçekleşir. Birincisi hükmetmek için objeye, âleme doğru çevrilir; ne kadar çok gerilirse objesine o kadar hâkim olur. İkincisi, orada başkalarını bulmak için kendi kendisine, kendi derin varlığına çevrilir ve ne kadar genişlerse varlıkla o kadar birleşir. Bu noktada Avrupa düşüncesinin evrimi birinci yönde, Doğu düşüncesinin evrimi ikinci yöndedir; fakat bu ayr1lış, fark edilecek derecede, Rönesans'tan sonra başlamaktadır (Ülken, 1964: 26). Ülken'in de ifade ettiği gibi Batı, yüzünü Doğu'ya çevirerek, "Doğululaşan Doğu” imajını yaratmaya çalışmaktadır.

Buradan hareketle Ülken, bu ayrımı felsefi derinliklere inerek açıklar. Maddecilikruhçuluk, varoluşçuluk-özcülük, içkin varlık-aşkın varlık şeklindeki zıt görüşleri bugün de sürüp gitmekte olup; bu karşıtlıklar Batı medeniyetinin içindeki gerginlikten ileri gelmektedir. Doğu'ya gelince, Hint de, Çin de ve İslam da tarihi bakımdan görüldüğü üzere, bu gerginliği yaşamıyor ve bundan dolayı onun aynı krizleri ve aynı tasaları yoktur; fakat kendi varlığına o kadar dalmıştır ki, bu şartlar altında objeye hükmetmesi ve onu kendi hizmetinde kullanması hemen hemen imkânsızdır. Ülken'e göre Şarkla Garp arasındaki kökten ayrılık buradan hareketle doğar (Ülken, 1964: 27). Bu ayrılığın doğmasında Batı'nın bilinçli ve art niyetle hareket ettiği çok rahat söylenebilmektedir. Çünkü kendi varlığına dalan Doğu'yu uyandırmadan, kendi hegemonyasına almak isteyen Batı, bu ayrılığı yaratarak amacına ulaşmak istemiştir.

Doğu-Batı ayrımı hakkında Baykan Sezer'in düşüncelerine bakıldığında ise, söz konusu ayrımın Batılılar tarafından inşa edildiği gözlenmektedir. Baykan'a göre Batının kendisi ile diğer toplumlar arasında bir ayrım yapılmaktadır ve bu ayrım en şiddetli şekilde sürdürülmektedir. Sanayi toplumları ve tarım toplumları ayrımı 20. yüzyılın başlarında Batı'nın kendisini diğer toplumlardan ayırma yolundaki ilk girişimidir. Daha sonraları sanayi toplumlarından, sanayi devrimini gerçekleştirmemiş toplumlardan söz edilmiş, gelişmiş ve az gelişmiş ülkeler ayrımı 20. yüzyılda toplumları sınıflandırmak için başvurulan en önemli ayrım olmuştur (Baykan, 1998: 42).

Doğu ile Batı arasında yaşanan ayrımın gelişim safhasını bu şekilde ifade eden Baykan, Batı ve Batı-dışı toplumlar arasındaki ayrımın çeşitli adlarla anıldığından söz 
etmektedir. Bu ayrım, Daha önceleri Kuzey-Güney ayrımıyken, günümüzde Doğu-Batı ayrımı olarak anılmaya başlanmıştır. 21. yüzyıldan bu tarafa Batı, egemenliğini Doğu'ya da yayma girişimindedir. Yeni ülkelerle geleneksel ilişkilerin dişında kurmuş olduğu ilişkiler Batı'ya çok büyük üstünlükler kazandırmıştır. Batı, başka bir yolla üstünlüğü sağlaması olanaksız da göründüğü için Doğu'ya aynı ilişleri dayatma yolunu seçmiştir. Gerçekte Batı egemenliğinin benimsenmesinden başka bir anlam taşımayan yeni ilişkilere uyum ise söz konusu ilişkilerin çağdaşlaşmak olarak tanıtılması şeklinde gerçekleşmiştir. Tarih dışı kalmış toplumlar için bu ilişkiler belki tarihe (aynı zamanda uygarlığa) katılmak için bir olanak oluşturmuştur. Ama tarihin her aşamasında etkin bir rol oynamış, büyük bir uygarlık olan, kendi çözümünü üretme yeteneğine sahip olan Doğu için geç̧ekte bir yıkım anlamını taşımıştır (Baykan, 1998: 43). Bu yıkımın hızlandırılması amacıyla gerçekleştirilen en önemli hareketlerin başında oryantalizm gelmektedir. Böylece Batı, kendisinin ortaya çıkardığı ayrım neticesinde, Batı-dışı toplumları "çağdaşlaştırmak" adına bir takım faaliyetlere gerçekleşmiştir. Aslında çağdaşlaştırmanın adı, emperyalizm ve sömürgecilik olduğu rahatlıkla görülebilir.

Batı'nın, Doğu'ya hükmetmesi ve onu kendi hizmetlerinde kullanması amaciyla gerçekleştirilen ayrımdan başka, daha derin bir ayrım yapılmaktadır. "Doğu” olmasaydı eğer, “Batı” da olmazdı. Batı’ya göre Doğu “öteki”dir. Diğer bir anlatımla kendisinin tamamen karşıtı olan "Doğu” yu icat ederek kendisini tanımlar. Bu ötekileştirme işlemiyle, kendisinde olan iyi şeylerin Doğu'da olmadığını ve kendisinde olmayan kötü şeylerin hepsinin Doğu'da bulunduğunu iddia eder. Oryantalist düzlemde Doğu, genellikle Batı'nın sahip olduğu varsayılan bilim, ilerleme fikri, demokrasi, akılcı düşünme vb. özelliklerle tanımlanır. Doğu kendini ifade edemez ve anlatamaz; ama Batı, hem kendisini anlatabildiği gibi bir de Doğu adına konuşur. Başka bir deyişle, Doğu kendi kendisini temsil edemiyorsa, temsil edilmesi gerekir. Oryantalizmin incelediği temel nesne Doğu'dur, aynı zamanda Batı'nın bizzat kendisiyle de ilgilidir. Batı'da, Doğu toplumlarını açıklamak için sunulan teoriler, Batı'nın üstünlüğünü daha belirgin bir şekilde göstermektedir (Bulut, 2004: 13-14).

Doğu ve Batı kavramları arasındaki ayrımların herhangi bir coğrafyaya ait olmadığına ve aralarında coğrafi ayrılıktan çok söylemsel ve ideolojik bir ayrım olduğuna daha önce değinilmiştir. Batı, kendisi ile diğer toplumlar arasında devamlı gerçekleştirdiği bu ayrımdan dolayı diğer toplulukları “öteki” olarak görme anlayışını devam ettirmiştir.

\section{Doğu-Batı Ayrımı ve Ötekileştirme}

Doğu-Batı ayrımının daha iyi anlaşılması için "öteki” kavramının üzerinde durulmasında fayda vardır. "Öteki” bilinci, kültürden kaynaklanan farklı sosyal davranışın sonucudur. "Öteki” tabiri, ayrı bir kültüre mensup olan insan veya grupları ifade etmek amacıyla kullanılmaktadır. Ayrı bir kültür ve yaşam tarzı geliştiren grup farklı olandır, 
“öteki”dir. Kültür ne kadar gelişmiş ise "farklılık”, “ben” ve “öteki” bilinci o kadar derin ve güçlü olur. Doğu kimliğinin ve “öteki”liğin politik ifadesi biçiminde varlık kazanan oryantalizm, Doğu'yu kurgusal bir çerçeve içine hapsetmiş ve öteki ile ilişkilerini de bu kurgusal çerçevedeki algılayışlarına paralel biçimde yeniden ortaya çıkarmıştır (Süphandağı, 2004: 49). Batı'nın kendi iradesi ile yarattığı ayrıma, oryantalizm kılıfı giydirilmiş, Batı-dışı toplumlar ise “öteki” olarak görülmüştür. Böylece Batı'nın, Doğu üzerinde uygulamaya çalıştığı emperyalizm meşru hale getirilmek istenmiştir.

Farklı bir kültüre mensup olarak görülen Doğu, tarihsel süreç içerisinde sürekli olarak öteki durumunda olmuştur. Çünkü Batı, kendinden farklı olana “öteki” demektedir. Böylelikle Doğu, Batı için her zaman "öteki” konumunda olmuştur. Ötekileştirme, aynı zamanda modernlik ve Batılılaşma gibi kavramları da beraberinde getirmektedir. Çünkü modernleşme olgusu da kendisinden farklı olanı ötekileştirmektedir. Modernlik, Batı'nın sahip olduğu kavramdır. Çoğu zaman batılılaşma, modernlik olarak algılanmış olup; birbirinin yerine kullanılmıştır. Oryantalizm ve emperyalizmin temelinde modernleşme söz konusudur; bu nedenle oryantalizm, emperyalizmin meşruiyetini sağlamaktadır.

Kültürlerin var olması zorunlu olarak ötekinin varlığını doğursa da, bu tanınma, yine zorunlu olarak, idealize edilmiş bir öteki algısıyla, dışlayıcı bir kültürel-siyasal söylemi gerektirmez. Kendisini, süreklilik oluşturan şekiller vasıtasıyla Doğu'nun aynasında tanımlayan Batılı düşünürler, bu tanımlamanın, hem tanımlayan hem de tanımlanan tarafıdır. Her durumun odak noktası Batı'dır. Bu işlemde Doğu hem kurulmakta hem de Doğu'nun dışta bıraktığı Batı, tanımlama öğelerinin olumlu ve olumsuz özellikleri üzerinden tanımlanmaktadır (Arlı, 2004: 22). Hem tanımlayan hem de tanımlanan Batı, bu şekilde Doğu'nun Doğululaştırılmasına zemin sağlamıştır.

Oryantalizm, Said tarafından bir "öteki” problemi olarak ortaya konularak, sosyal bilimlerin temel konularından biri haline gelmiştir. Hilmi Yavuz’a göre ise, Batı, Yunan çağından beri, kendisini “öteki”"nden farklı ve üstün görür. Ötekini kendinden aşağı bir insan türü, kendisini ise hakiki insan olarak kabul eder. Bu düşünceden yola çıkarak, daha fazla insan olan kendisinin, daha az insan olan ötekini temsil etme hakkı olduğuna inanır. Ötekinin bu ontolojik “nesne”liği ve Batı'nın ontolojik “özne”liği, oryantalizmin de ontolojik temelidir. Buna göre Doğu, ne kendini ne de Batı'yı bilebilir. Dolayısıyla ne kendini ne de Batı'yı tanımlama yetkisine ve hakkına sahiptir. Oryantalizm, hem Batı için hem de Doğu'nun kendisi için Doğu'yu temsil görevini gönüllü olarak yapar. Yani Yavuz da, Said gibi oryantalizmi ontolojik yönüyle ele almış olup; Doğu'yu “nesne”, Batı'yı ise "özne” olarak değerlendirmiştir. Doğu kendini tanımlayamaz, savunamaz onun bir başkası tarafından temsil edilmesi gerekir; bu işlevi yapacak olan ise "Batı"dır (Yavuz, 1999: 41). O halde bu açıklamalardan anlaşıldığı üzere, oryantalist bakış açısına sahip bir şekilde hareket eden Batılı zihniyetin, antik döneme kadar gerilediği görülmektedir. Belki de Aristoteles ve Platon'dan başlayarak, Hegel ve Kant'a kadar, sürekli Doğu'yu küçümseyerek ve hor görerek süregelen 
Batılı tarih felsefelerinin arka planında bu anlayış yer almaktadır. Çünkü antik dönemden günümüze kadar dile getirilen tarih felsefelerindeki ortak nokta, Avrupa'nın en üst noktada yer alması ve Doğu toplumlarının sürekli dışlanması ve aşağı seviyede görülmesi şeklinde olmuştur.

Said, "Oryantalizm" adlı eserinde, Batı-dışı ötekinin Batılı modern benliğin kurulma sürecinde içsel yapısını anlatmakta, modern benliğin nasıl farklı olanı ötekileştirerek kurulduğunu tarihsel ve söylemsel olarak çözümlemektedir. Said'e göre, Aydınlanma sonrası dönemde Avrupa kültürü, kendi kimliğini, kendisini "Doğu” olarak tanımlayan kimliğe karşı konumlandırmıştır. Oryantalizm, Batı'nın Doğu'yu, Batı-karşıtı kimlik olarak üreterek kendi hegemonyasını dünya üzerinde kurma sürecidir. Dolayısıyla da farklı olanın ötekileştirilmesidir. Doğu ve Batı arasındaki ayrım temelinde öteki, Avrupa'nın maddi ve manevi (kültürel) uygarlığının ayrılmaz bir parçası olarak kurulur. Batı, böylece kendisini modern, gelişmeye açık, demokratik, kalkınmacı ve bireyci gösterirken, farklı olana kendisinin zıttı özellikler atfeder (geleneksel, azgelişmiş, otoriter, toplulukçu gibi). Böylece farklı olan Batı'nın ötekisi konumuna getirilir ve Batı tarafından ortaya çıkarılır (Keyman, 2002: 21). Öteki olarak adlandırılan Doğu'nun üzerinde hâkimiyeti sağlamak adına öncelikle Doğu-Batı ayrımı denen ayrım gerçekleştirilmiş ve Batı kendi varlığını üstün mertebeye getirerek Doğu'yu farklı görmüştür. Günümüzdeki Doğu-Batı ilişkisini göz önüne getirmek, bu durumun daha iyi anlaşılmasına yardımcı olacaktır. Çünkü günümüzde bile Batı-dışı toplumların, Batı tarafından ötekileştirildiği bir toplum olmalarını sağlamak adına sömürgeleştirildiği görülmektedir.

Bu noktada, Said'e göre önemli olan şudur: Oryantalizm Doğu-Batı, Birinci DünyaÜçüncü Dünya, Kuzey-Güney, Modern-Geleneksel arasındaki karşıtlıktan hareket ederken, yapılmak istenen, farklı olanın anlaşılması değil, tersine Batılı benliğin anlatılması, bireyselliğinin ve akılcılığının meşruiyetinin sağlanmasıdır. $\mathrm{Bu}$ anlamda oryantalizm, Doğu'yu anlatmaz; onu Batı gözüyle kurar ve bu süreç içinde de Batı'ya yani modern olana yöneliktir. Sonuçta "öteki” bir nesne ya da bir varlık değil, söylemsel bir kurgudur. Oryantalizm, kurumsal, siyasal, ekonomik, kültürel, söylemsel ve tarihsel olarak Batı epistemolojisinin Doğu'yu algılama, onu kendi zıttı olarak kurma, böylece de kendi varlığını hegemonik olarak evrenselleştirme sürecidir. Neticede oryantalizm, farklı olanın söylemsel olarak ötekileştirilmesi eylemidir (Keyman, 2002: 22).

\section{Oryantalizm ve Emperyalizm İlişskisi}

\section{Emperyalizm Kavramı ve Tarihsel Gelişimi}

Oryantalizm ve emperyalizm ilişkisinin temelinde Doğu-Batı ayrımının yapılması ve bunun neticesinde ortaya çıkan "ötekileştirme" problemi olduğuna daha önce değinilmiştir. Öncelikle "Emperyalizm"in ne olduğuna kısaca değinmek gerekirse, genellikle bir devlet ya 
da ulusun bir başka ülke ya da halk üzerinde güç oluşturması anlamında kullanılır. Bu güç, bir devletin politik kontrolü altında tuttuğu koloni ya da devlet durumun getirdiği topraklar üzerinde resmi otorite kullanılması şeklinde olabileceği gibi politik, ekonomik ve kültürel etki altına almak gibi resmi olmayan yollarla da kullanılabilir. Bu terimin kullanılması çok eskilere dayanmakla birlikte asıl 19. yüzyılda kullanılmaya başlanmıştır. Tarihsel süreç içerisinde emperyalizm değişik dönemlerden geçmiştir (Görsel Dünya Ansiklopedisi, 913).

Emperyalizmin ilk dönemleri eski çağa dayandırılabilir. Eski çağlarda Babil, Asur, Mısır, Pers, Yunan ve Roma imparatorlukları yabancı toprakların ele geçirilmesine ve buradaki halkın sömürülmesine dayanmaktadır. İkinci dönem (15. yy- 16. yy), Avrupa ticaret sömürgeciliğidir. Avrupalı güçler (İspanya, Britanya, Portekiz gibi) kendi donanmalarıyla denizleri denetim altına alıp başlıca ticaret merkezlerini kurdular ve bazı büyük bölgeleri de ele geçirmiştir. Bunlarla birlikte "modern emperyalizm" de denilen, emperyalist yayılmanın üçüncü dönemi, 1870’lerde başladı ve ikinci dünya savaşı bitiminde sona ermiştir. Bu dönemde Avrupalı güçler ve ABD arasında bir sömürgecilik yarışının sürdügü görülür. Büyük Britanya ve Fransa'nın yanı sıra Belçika, Almanya ve İtalya da, bu yarışta yer almışlardır. (Görsel Dünya Ansiklopedisi, 913). Batılı tarihçiler tarafından 19. yüzyıl, genel olarak 1789 yılıyla başlatılır. $\mathrm{Bu}$ tarih Doğu-Batı ilişkileri açısından dönüm noktası olarak değerlendirilebilir. Burada Doğu-Batı ilişkileri açısından önemli olan Napolyon Bonapart'ın 1798 Mısır seferidir. 19. yüzyılda dünya sistemini oluşturan en önemli unsur olarak Batı'nın yükselmesi ve Batıl1-olmayan toplumların buna cevap üretememesi olarak görülmektedir. Dünya sisteminde büyük ve önemli güçler olan Osmanlı İmparatorluğu, Çin İmparatorluğu, Hint-Babür Sultanlığını, Fas Murabıt Devleti gibi belli başlı güçler ticari ilişkilerde, askeri rekabette, sosyal ve kültürel alanda konumlarını kaybetmiştir. Aynı zamanda Batı dışı toplumların daha önce belirtilen Avrupa-merkezci bakış açısından incelenmesi bu egemenlikle eş zamanlı olarak başlamıştır. Emperyal projenin ilk başarısı ilk kez dünya medeniyetleri ile aynı seviyeye çıkan Batı'nın diğer medeniyetlere karşı asimile edici tavır takınmasına neden olmuştur (Sunar, 2007: 40-41).

Doğu-Batı kavramları bağlamında konuya yaklaşıldığında Rana Kabbani, "Elizabeth Çağı İngiltere'nin bir ticaret imparatorluğuna soyunmasının doğal sonucuydu. Meraklı tüccarların, ülke toprakları dışına taşan yeni pazarlar bulmak üzere, dışarı açıldıkları, yolsuzluklara "vatanseverlik" adını verdikleri, gelecekte var olacak olan imparatorluğun temellerinin atıldığı dönemin bu dönem"2 olduğunu belirtmiştir. Burada sözü edilen tüccarların sömürgeci arzuları, “öteki” olarak kabul ettikleri Batı-Dışı toplumlar, yani Doğu toplumları için geçerli arzulardır. Batılıların sömürgeciliği meşru hale getirmek adına önem verdikleri oryantalizm hareketi, bu bakımdan emperyalizm ile çok yakın ilişki içerisinde bulunmaktadır.

\footnotetext{
${ }^{2}$ Rana Kabbani, Avrupa'nın Doğu İmajı, (Çev. S.Tuncer), Bağlam Yayınları, İstanbul, 1993, s.52.
} 
Emperyalizmin ilk olarak 1870'lerde, Fransa'da III. Napoleon'un siyasal ve askeri amaçlarını karşılamak amacıyla kullanılan ve daha sonra da büyük devletlerin rekabetini anlatmak için kullanılan bir terim olduğu yukarıda belirtildi. Günümüze yaklaştıkça ise, gelişmiş ülkelerin sömürge ülkeler üzerindeki egemenliğine karşılık gelmektedir. Dolayısıyla sömürgeciliğin eşanlamlısı haline gelmiştir. Avrupa'nın denetiminin 1870'den sonra genişleyerek artmasına açıklamalar getirmeye çalışan emperyalizm kuramları üç kategoride toplanabilir.

\section{Oryantalizm ve Emperyalizm İlişkisi}

Oryantalizm ve emperyalizm arasında bulunan ilişkiden daha önce kısaca söz edilmişti. Doğu-Batı ayrımı ve bunun beraberinde gelen "öteki” yaftası ile birlikte emperyalist hareketler gerçekleşmiş ve bu hareket oryantalizm ile ilişkilendirilmiştir. Bu açıklama ile ilgili düşüncelerini dile getiren Jale Parla’ya göre, “sömürgeleştirilecek olan Doğu’nun, Avrupalı emperyalist güçlerle öğrenilmesi ve uygulanılacak politikaların belirlenmesi kaygısının sonucu olan oryantalizm, Avrupa'daki sömürgecilikle eş zamanlı ve eş amaçlı olarak doğmuştur." (Sarınay ve Sünbül, 1999: 12-13). Bu açıklamadan anlaşıldığı üzere, oryantalizmin diğer adı emperyalizm olarak görülmüştür.

19. yüzy1la gelindiğinde, oryantalizm, temsil ettiği güçlerin hedefi olan siyasal ve sosyolojik coğrafya ile örtüşmüş ve Hıristiyanlığın kurtarıcılık misyonu ile bütünleşmiştir. Böylece sömürgecilik, Avrupa'nın, geri kalmış Doğu'yu kurtarmasının görevi olduğu, bunun için de Doğu'yu egemenliğine alması gerekliliğine dayandırılmıştır. O dönemde Osmanlı Devleti’nin egemen olduğu coğrafyayı da kapsayan Doğu sorununa bilimsel destek sağlayan Oryantalizm, sömürgeciliğin meşruluğunu kazanmasına hizmet etmiştir. Anwar Abdel Malek'in bu yaklaşımı oryantalizme daha önce yapılmamış bir biçimde felsefi ve bilgesel bir statü vermiş ve bu statüyü doğrudan "sömürgecilik" koşuluyla ilişkilendirmiştir. Aynı şekilde Edward Said de bu yönde ilerlemiş ve oryantalizm kavramı, sömürgeci bir zihniyeti ve kuruluşu ifade eden söylemsel bir figür olarak belirlenmiştir. Malek'in makalesinin asıl özgün yanı ise, (Hegel'in efendi-köle diyalektiği sorunsalını belirli bir biçimde ve yönde kullanarak) oryantalizmin epistemolojik yönünü vurgulamasıydı. Doğulunun özsel pasifliği, onun doğası itibariyle kendi gerçeği hakkında kendisi konuşamayan ve yazamayan ve esas olarak hakkında konuşulan ve yazılan bir bilgi nesnesi olarak konumlanması anlamına gelen çok ince bir entelektüel bir inançtı (Mutman, 2004: 190-191).

Oryantalizm isimli eserinden 16 y1l sonra ve bir anlamda bu kitaba devam niteliğinde yazdığ "Kültür ve Emperyalizm" adlı çalışmasında Said, bir yandan kendisini izleyen ve eleştiren araştırmacıların eleştirilerini dikkate alırken, bir yandan da Oryantalizmin her zaman emperyalizmle el ele gittiğini tekrar etmiştir (Said, 2004). Bu açıklama da, Jale Parla'nın açıklamaları ile paralellik göstermekte ve oryantalizm ile emperyalizmin sahip oldukları benzerlikleri ortaya koyma noktasında önemli görülmektedir. 
Oryantalizm ile emperyalizm arasındaki ilişkiden bu şekilde söz eden Edward Said, bu ilişkinin nasıl bir çıkar çatışması olduğunu, şu sözleriyle açıklamaktadır (Said, 1998: 45):

Avrupalılar, uzak yerlerde varlıklarını bildikleri zenginlikle ve onlara sahip olmak için harekete giriştiler. Denizaşırı ülkelere gidip ilişki kurarak o bölgelerin zengin varlıklarını Avrupa'ya akıttılar. Avrupa'ya akıtılan bu zenginlikler Batı devletlerinin yeni pazarlar aramasına, ulaşım için yolların yapılmasına ve gemi ulaşımı tekniğinin gelişmesine sebep oldu. Bu sayede İspanyollar, Portekizliler, Hollandalılar, Fransızlar ve İngilizler dünyanın çeşitli bölgelerinde yeni sömürge bölgeleri elde ettiler. Amerikalılar Doğu'yu geleneksel ve egzotik açıdan değil stratejik ve ekonomik değerleri ile görüyorlardı. Doğu bir mitolojik varlık olmaktan gittikçe uzaklaşıyordu. Bu varlığın içinde Batı'lıların ve özellikle Amerikalıların vazgeçilmez çıkarları yer alıyordu.

Oryantalizmle emperyalizm arasındaki bütünsellik ilişkisi, sadece kuramsal düzeyde değil, oryantalizmin sonuçları bağlamında da söz konusudur. Çünkü her kim olursa olsun ve hangi amaçla yaparsa yapsın oryantalistlerin dile getirdikleri mesajlar, farklı bir içeriğe sahip olmamaktadır. Örneğin ister akademisyen olsun, ister roman yazarı olsun, bu durum aynı şekilde gerçekleşmektedir. Ayrıca bu konuda oryantalizmin, İslam söz konusu olduğunda dört ilkede belirtilebilecek çizgileri vardır (Sayyid, 2007: 68):

- Batı ile Doğu arasında mutlak ve sistematik bir fark vardır.

- Doğu'nun temsili, modern oryantal gerçeklerden ziyade metinsel yorumlara dayalıdır.

- Doğulu değişmezdir, tek biçimlidir ve kendini ifade etme yetisine sahip değildir.

- Doğu, korkulacak veya kendisine efendilik yapılacak olandır.

$\mathrm{Bu}$ çalışmada oryantalizm ile emperyalizm arasında kurulan ilişkiyle bağlantılı olarak görüş bildiren Cemil Meriç de, oryantalizmin, farklı biçimlerde sömürgeciliğin keşif kolu olarak rol oynadığını dile getirmektedir. Cemil Meriç'e göre şarkiyatçılık herhangi bir kültürel belirlenim değildir. Onu diğerlerinden ayıran nokta, kasıtlı ve bilinçli bir şekilde başka bir toplum üzerinde kurduğu egemenlikle girdiği ilişkidir. Şarkiyatçılık, Doğu'nun kendi kimliğini oluşturmasının da ötesinde, Batılı olanın şeklini ve yönünü belirlemiştir. Edward Said'in de belirttiği gibi (Sunar, 2007: 42):

Şarkiyatçılık, Şark’a ilişkin uçuk bir Avrupalı hülyası değildir, nesillerdir önemli parasal yatırımların yapıldığı, yaratılmış bir kuram ve uygulama bütünüdür. Süregiden yatırımlar, nasıl şarkiyatçılıktan türeyerek genel kültüre giren önermeleri çoğaltmış, bunları gerçekten üretken kılmışsa Şark’a ilişkin bir bilgi dizgesi olarak şarkiyatçılık da Şark’ın Batı bilincine süzülerek girmesini sağlayan, onanmış bir düzenek haline gelmiştir. 


\section{Sonuç ve Değerlendirme}

Bir ideoloji olarak kabul edilen oryantalizm, kısaca Batı'nın, Avrupa dışında yer alan Doğu toplumlarıyla aralarındaki farklılıkları göstermek adına ortaya çıkartılmıştır. Bu nedenle Batı, kendisinden ayırmış olduğu Doğu'yu, yine kendi kafasına göre tekrardan yorumlamaktadır. Bu nedenle, Batı'nın yorumladığı Doğu ile asıl Doğu toplumları arasında herhangi bir benzerlik bulunmamaktadır. Çünkü Batı, kendisi dışında hiçbir toplumun tarihini ve kültürünü kabul etmemekte ve kendi dışındaki toplumların tarihini ve kültürünü, kendini merkeze alarak tekrardan yazmaktadır. Yani Batı, kendi "Doğu"sunu yaratmış olmaktadır. Dolayısıyla ortaya, Batı'nın kurguladı̆̆ı bir "Doğu” çıkıyor. Bu kavram coğrafi anlamdan öte bir ideolojiden ibarettir.

Batı'nın bu kadar kendini merkezi görmesi ve başka toplumları kendisinden ayrı görmesinin arka planında neler yatmaktadır? Batı, kendisi dışındaki Doğu toplumlarını “öteki” olarak görmeye başlamasıyla birlikte, bu ayrımı gerçekleştirmiş oluyordu. Doğu-Batı ayrımını ortaya çıkaran Batı'ya göre, Doğu'nun kültürü ve tarihi yoktur. Bu nedenle Batı zihniyeti, kendi kültürünü Doğu'ya aktarma girişimi ile birlikte, bir nevi oryantalist davranmış oluyorlardı. Çünkü Doğu'ya önce kültür girecek, ki bu Batı kültürü olmakta, sonra da Batı'nın emperyalist emelleri sahneye çıkacaktır. Modernizm ve batılılaşma gibi bir takım ideolojilerin yaratılması ile birlikte, Batı'nın kültürel sömürüsü hızlanmış oluyordu. Bu gelişmeler yaşanırken, Doğu'nun kendi insanı da bu modernleşme ve batılılaşma hareketlerini destekler hale gelmesi ve hatta birçok toplumun, bu durum Osmanlı Devleti ve Türkiye Cumhuriyeti Devleti'nde de yaşanmıştır, bu hareketleri çözüm yolu olarak görmesi, kültürel sömürüyü hızlandırmıştır. $\mathrm{Bu}$ durumda Batı, saman altından su yürütürken, kültürel sömürüsünü de tamamlamış olacaktır. Bundan sonra toprak zenginliği fevkalade olan Doğu'nun, bu zenginliklerinin sömürüsü hareketi başlayacaktır.

Görüldüğü gibi Doğu-Batı ayrımı ve Batı'nın, Doğu'yu kendisinden farklılaştırması neticesinde ortaya çıkan "ötekileştirme" problemi, az önce değinilen modernleşme ve batılılaşma hareketlerinin de tuzu biberi olmuştur. Aslına bakılırsa, bu hareketler de ötekileştirme ile eş değerdir. Fakat unutulmaması gereken bir nokta var; o da modernleşme ve batılılaşma adı verilen hareketlerin ortaya çıkış kaynağı, yine Batı'nın kendisidir. $\mathrm{Bu}$ kavramlar, Doğu toplumları tarafından ortaya çıkartılmamıştır. Batı, modernleşme ve batılılaşma gibi fikirlerle, Doğu toplumları üzerindeki emperyalist emellerini gerçekleştirme adına ideolojik altyapıyı sağlamış olmakta ve Doğu üzerindeki politikalarının ilk ayağı olan kültürel sömürü hareketini gerçekleştirmektedir.

Günümüzde bile hala Batı'nın ne kadar modern ve medeni olduğu dile getirilmektedir. $\mathrm{Bu}$ çalışmada ele alınan konulardan yola çıkılırsa, Batı'nın "Doğululaştırdığı bir Doğu" vardır. Batı'nın doğululaştırmak istediği Doğu'nun, aslında sahip olduğu eşsiz bir kültür ve medeniyetten söz etmek mümkündür. Fakat oryantalistlerin en büyük arzuları da, bu kültür ve 
medeniyeti hiçe saymak ve kendi kültürlerini Doğu'ya empoze etmektir. $\mathrm{Bu}$ nedenle "Doğu'nun Doğululaştırılması" şeklinde bir tabir literatürde ve Edward Said'in Oryantalizm kitabında yer almaktadır. Batı, Doğululaştırdığı Doğu üzerine ortaya çıkardığı zihniyetle, Doğu'yu gelişmemiş olarak kabul etmektedir. Çünkü Batı, kendisinden başka hiçbir toplumda olmadığını düşündüğü kültür ve medeniyeti, dünya geneline yayarak, özellikle Doğu’yu etkisi altına almak ve hâkimiyetini Doğu üzerinde gerçekleştirmek istiyordu. Bu nedenle bütün bu emellerin temelinde yer alan emperyalizmi meşru hale getirmek isteyen Batı, modernleşme ve batılılaşma gibi kavramları inşa ederek, Doğu-Batı ayrımını gerçekleştirmiş ve Doğu'yu Doğululaştırmıştır.

\section{Kaynaklar}

Arlı, Alim (2004). Oryantalizm-Oksidentalizm ve Şerif Mardin, İstanbul: Küre Yayınları.

Bulut, Yücel (2004). Oryantalizmin Kısa Tarihi, İstanbul: Küre Yayınları.

Germaner, Semra ve İnankur, Zeynep (1989). Oryantalizm ve Türkiye, İstanbul: Türk Kültürüne Hizmet Vakfı Yayınları.

Görsel Dünya Ansiklopedisi, “Emperyalizm”, Cilt 4, Görsel Yayınları, İstanbul.

Kabbani, Rana (1993). Avrupa'nın Doğu İmajı, Çev: S.Tuncer, İstanbul: Bağlam Yayınları.

Keyman, E.Fuat (2002). “Globalleşme, Oryantalizm ve Öteki Sorunu: 11Eylül Sonrası Dünya ve Adalet", Oryantalizm-II, Doğu-Batı Dergisi, Say1:20, Ankara.

Kızılçelik, Sezgin (2003). Küreselleşme ve Sosyal Bilimler, Ankara: Anı Yayınları.

Lugarhi, Raimondo (2000). Sömürgecilik Tarihi, Çev: Halim Ünal, İstanbul: E Yayınları.

Mutman, Mahmut (2004). "Şarkiyatçılık/Oryantalizm”, Modern Türkiye’de Siyasi Düşünce, Cilt 3, İstanbul: İletişim Yayınları.

Said, Edward (2004). Kültür ve Emperyalizm, Çev: Nemciye Alpay, Adıyaman: Hil Yayınları.

Said, Edward (1998). Oryantalizm, Çev: Nezih Uzel, İstanbul: İrfan Yayınları.

Sarınay, Yusuf ve Sünbül, Tahir (1999). Emperyalizm ve Büyük Hayal, Ankara: Günce Yayınlar1. 
Sayyid, Selamn (2007). "Oryantalizmden Sonra”, Çev. Hakan Çopur, Uluslar arası Oryantalizm Sempozyumu, İstanbul: İstanbul Büyükşehir Belediyesi Kültür Müdürlüğü Yayınları.

Sezer, Baykan (1998). “Doğu Batı Ayrımı”, Doğu Ne? Batı Ne?, Doğu Batı Dergisi, Sayı 2, Ankara.

Sönmezsoy, Selahattin (1998). Kuran ve Oryantalistler, Ankara: Fecr Yayınları.

Sunar, Lütfi (2007). “Şarkiyatçılığı Niçin Yeniden Tartışmalıyız?”, Uluslar arası Oryantalizm Sempozyumu, İstanbul: İstanbul Büyükşehir Belediyesi Kültür Müdürlügü Yayınları.

Süphandağı, İsmail (2004). Batı ve İslam Arasında Oryantalizm, İstanbul: Gaye Kitabevi.

Şentürk, Recep (2003). Oryantalizm ve Sosyal Teori, Oryantalizmi Yeniden Okumak Batı'da İslam çalışmaları Sempozyumu, (11-12 Mayıs 2002 Adapazarı), Ankara: Diyanet İşleri Başkanlığı Yayınları.

Ülken, H.Ziya (1964). “Şark-Garp Problemi Karşısında İslamiyet”, Ankara Üniversitesi İlahiyat Fak. Dergisi Yayınları, Cilt XII, Ankara.

Yavuz, Hilmi (1999). Modernleşme, Oryantalizm ve İslam, İstanbul: Boyut Kitapları. 